\title{
Analysis of perinatal mortality in newborn infants with a birth weight of less than 1000 grams in Hospital San Cecilio in Granada (Spain) over the 1991-2010 period
}

\author{
Milagros Cruz Martíneza, M.D., Rosario Redondo Aguilara, B.S., \\ África Caño Aguilara , M,D., Pilar Carretero Lucena ${ }^{a}$, M.D., \\ Carmen Padilla Vinuesa ${ }^{a}$, M.D., and Ángeles Ruiz Extremera ${ }^{b}$, M.D
}

\begin{abstract}
Introduction. Perinatal mortality has significantly decreased over the last decades. Low birth weight and prematurity are amongst the strongest predictors of neonatal death. The main objective is to analyze the evolution of perinatal mortality and its causes in newborn infants with a birth weight of less than 1000 grams over the last 20 years (1991-2010).

Population and Methods. Observational, descriptive, longitudinal and ecological study. A total of 264 infants weighing less than $1000 \mathrm{~g}$ out of a total of 56024 births during the study period. Different specific perinatal mortality rates by weight were calculated. The Spearman's Rho correlation coefficient was applied to assess the relationship between mortality rates and years of study, and ANOVA and Mann-Whitney test were used to compare five-year periods and tenyear periods, respectively.

Results. There were 131 perinatal deaths, 82 stillbirths and 49 early neonatal deaths; $64.1 \%$ of them occurred before 27 weeks of gestation. Only the fetal mortality rate was statistically significant, although perinatal mortality showed a downward trend, without reaching significance. The main immediate causes of death were extreme prematurity, intrauterine hypoxia and infection. The underlying causes related to death in this group of newborn infants were infection caused by premature rupture of membranes, maternal hypertension, uncontrollable preterm labor and twin pregnancy.
\end{abstract}

a. Obstetrics and Gynecology Clinical Management Unit.

b. Pediatrics Clinical Management Unit. Hospital Universitario San Cecilio. Granada. España.

E-mail:

Milagros Cruz

Martínez, M.D.:

mcruzmar@yahoo.com

Conflict of Interest:

None.

Received: 04-30-2012 Accepted: 07-27-2012 marked reduction, but still more than 7 million children die over this period around the world every year. ${ }^{2}$ The percentage in Europe is 4.5-8.7\%, in Spain it is approximately $5 \%{ }^{4}$ Such reduction has been caused by an improvement in population health and the health care received by mothers and newborn infants ${ }^{5}$ and, especially, by the development of new technologies to monitor fetal well-being and neonatal care.

Low birth weight (LBW) is the main individual factor that determines the newborn's likelihood of survival and healthy growth and development. As a consequence, prematurity and LBW are the predictive factors most strongly associated with mortality, with a direct relation between birth weight and perinatal mortality. ${ }^{1,3}$

This research focuses on the group of newborn infants with a birth weight of less than $1000 \mathrm{~g}$, categorized by the International Classification of Diseases and Related Health Problems 10th Revision (ICD-10), ${ }^{6}$ as extremely low birth weight. Improving survival and avoiding the causes leading to birth in this age group and weight range may have an impact on perinatal mortality reduction.

The objective of the study is to analyze the evolution of perinatal mortality in newborn infants with a birth weight of less than $1000 \mathrm{~g}$ in Hospital Universitario San Cecilio, (HUSC) in Granada (Spain) over the 1991-2010 period.

It is completed with the analysis of perinatal mortality causes in this group of newborn infants and maternal conditions and obstetrical and neonatal pathologies that contribute to mortality. 


\section{POPULATION AND METHODS}

Design: Observational, descriptive, longitudinal and ecological study.

\section{Population}

From January 1, 1991 to December 31, 2010 (temporal series: 20 years), there were 264 newborn infants with a birth weight of less than 1000 g out of 56024 births in the HUSC in Granada (Spain). There were 131 perinatal deaths within the study group out of 417 perinatal deaths.

Exclusion criteria: Newborn infants with a birth weight of less than $500 \mathrm{~g}$ or more than $999 \mathrm{~g}$.

\section{Method}

Descriptive analysis of different endpoints.

The different mortality rates recommended by the $\mathrm{WHO}^{6}$ (fetal, early neonatal and perinatal death) were estimated and applied to newborn infants with a birth weight of 500-999 $\mathrm{g}$ in this study.

The Spearman's Rho correlation coefficient was used to assess the relation between the different mortality rates and the years of study (temporal trend).

After grouping the study period in four fiveyear periods and two ten-year periods, the different mean rates under study were compared. An ANOVA test of a post hoc factor adjusted with Bonferroni's method was used to compare fiveyear periods, and a Mann-Whitney test was used to compare ten-year periods.

The statistical software used was SPSS 15.00, and differences were considered statistically significant if they had a $p$ value of $<0.05$.

Hospital autopsies were always performed by the same person and mortality causes were ana- lyzed by the same team; each case was discussed and analyzed, together with the consistency between the clinical diagnosis and the anatomical pathology report.

\section{RESULTS}

A total of 264 newborn infants with a birth weight of $500-999 \mathrm{~g}(0.47 \%$ of total newborn infants) were studied.

A total of 131 perinatal deaths occurred in the studied group (500-999 g), which accounts for $31.41 \%$ of all perinatal deaths.

\section{Analysis of mortality during the perinatal period according to the week of gestation (WG) at the moment of birth}

Table 1 reflects mortality and shows that a larger number of perinatal deaths occurred before WG 24 (38.9\%), followed by WG 24-26 (25.2\%).

The assessment of the time of perinatal death shows that fetal deaths are also more frequent before WG 24 (40.2\%). This was also observed in early neonatal deaths (36.7\% before WG 24$)$, essentially because all extremely premature newborn infants die over the first days of birth.

\section{Analysis of mortality rates (Figure 1)}

The total of 131 perinatal deaths was divided in 82 fetal deaths and 49 early neonatal deaths.

The mean fetal mortality rate was $308.66 \pm$ $133.85 \%$, with $500 \%$ in 1991 and $250 \%$ in 2010. In spite of its wide extent $(0-555.5 \%)$, a significant reduction has been achieved (Rho: -0.538) $(p=0.015)$.

The mean early neonatal mortality rate was $300.84 \pm 206.17 \%$, also with wide ranges over the years of study $(0-800 \%)$, and this has resulted in not reaching significance (Rho: 0.065$)(p=0.784)$.

TABLE 1. Distribution of mortality over the perinatal period in newborn infants with a birth weight of less than $1000 \mathrm{~g}$, by week of gestation at the time of birth

\begin{tabular}{lccc}
\hline Week of gestation & Perinatal deaths n (\%) & Fetal deaths n (\%) & Early neonatal deaths n (\%) \\
\hline$<24$ & $51(38.9)$ & $33(40.2)$ & $18(36.7)$ \\
$24-26$ & $33(25.2)$ & $18(22)$ & $15(30.6)$ \\
$27-28$ & $29(22.1)$ & $19(23.2)$ & $10(20.4)$ \\
$29-30$ & $9(6.9)$ & $7(8.5)$ & $2(4.1)$ \\
$31-32$ & $5(3.8)$ & $4(4.9)$ & $1(2.1)$ \\
$>32$ & $1(0.8)$ & $1(1.2)$ & $0(0)$ \\
Unknown & $3(2.3)$ & $0(0)$ & $3(6.1)$ \\
Total & $131(100)$ & $82(62.6)$ & $49(37.4)$ \\
\hline
\end{tabular}

Only newborn infants with a birth weight of 500-999 $\mathrm{g}$, were considered for the extremely low birth weight group, as recommended by the $\mathrm{WHO}$.

$\%$ : percentage. 
The perinatal mortality rate was $508.12 \pm$ $191.76 \%$, also with a wide range $(0-857.14 \%)$, but it showed a downward trend (Rho: -0.244$)$, which was not significant $(p=0.3)$.

The distribution of the period in four five-year periods and the comparison of their means (Table 2) show that only fetal mortality had statistically significant differences from the first five-year period (1991-1995) to the third five-year period (2001-2005).

There were no significant differences regarding early neonatal mortality or perinatal mortality.
In order to complete the study, we analyzed if there were differences between the various mean rates in the two ten-year periods of the study (Table 3), and we found that only fetal mortality shows statistically significant differences.

\section{Causes of death}

A total of 88 perinatal autopsies were performed; of these, 59 corresponded to fetal deaths and 29 were early neonatal deaths.

The clinical diagnosis and the results of the anatomical pathology report were consistent in $86 \%$ of the fetal mortality group and in $80 \%$ of the

FIGURE 1. Mortality over the perinatal period in newborn infants with a birth weight of less than 1000 grams

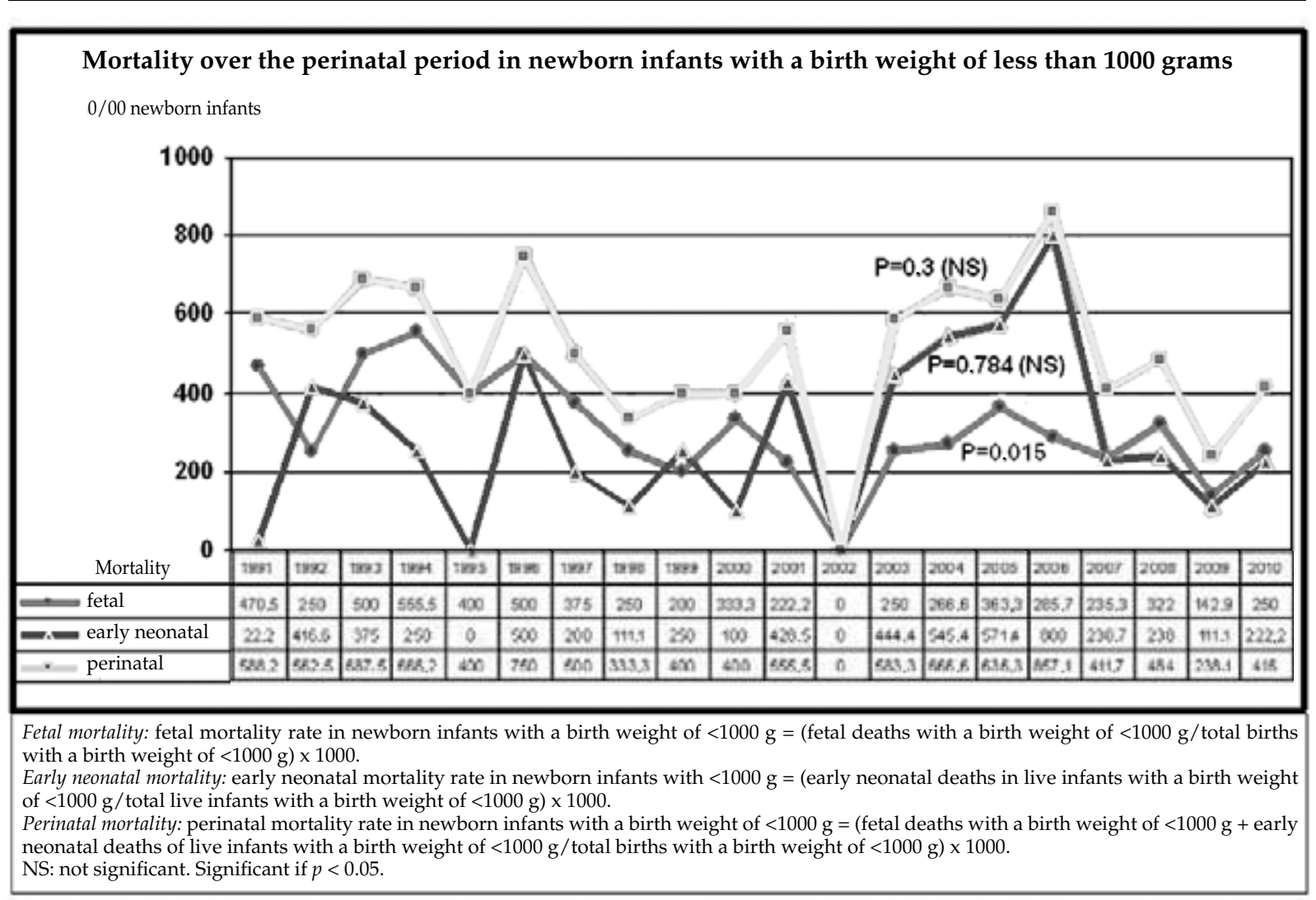

TABLE 2. Analysis of mortality rates over the perinatal period distributed in five-year periods. ANOVA test

\begin{tabular}{lccccc}
\hline & $\begin{array}{c}\mathbf{1 9 9 1 - 1 9 9 5} \\
\text { mean } \pm \text { SD }\end{array}$ & $\begin{array}{c}\mathbf{1 9 9 6 - 2 0 0 0} \\
\text { mean } \pm \text { SD }\end{array}$ & $\begin{array}{c}\text { 2001-2005 } \\
\text { mean } \pm \text { SD }\end{array}$ & $\begin{array}{c}\mathbf{2 0 0 6 - 2 0 1 0} \\
\text { mean } \pm \text { SD }\end{array}$ & p \\
\hline Fetal mortality rate & $435.21 \pm 117.75^{*}$ & $331.66 \pm 116.4$ & $220.50 \pm 134.26^{*}$ & $247.27 \pm 67.43$ & $0.033^{*}$ \\
Early neonatal mortality rate & $252.77 \pm 163.27$ & $232.22 \pm 162.18$ & $397.97 \pm 230.92$ & $320.41 \pm 273.07$ & 0.612 \\
Perinatal mortality rate & $580.97 \pm 113.83$ & $476.66 \pm 163.97$ & $488.38 \pm 276.46$ & $486.48 \pm 222.38$ & 0.834 \\
\hline
\end{tabular}

After applying an ANOVA test of a post hoc factor adjusted with Bonferroni's correction, statistically significant differences were found only in the 1991-1995 and 2001-2005 five-year periods in relation to fetal mortality.

SD: standard deviation; $\mathrm{p}$ : value of significance; ${ }^{*}$ : $\mathrm{p}<0.05$. 
neonatal mortality group; for the rest, the cause of death was established by the autopsy.

The main immediate causes of death (Table 4) were extreme prematurity $(23.7 \%)$, intrauterine hypoxia $(22.9 \%)$ and infection $(15.3 \%)$. Hyaline membrane disease was present in 9 cases $(6.9 \%)$, and malformation occurred in 11 cases $(8.4 \%)$. Other pathologies included 4 cases of twin-to-twin transfusion syndrome and 7 cases of intrauterine growth retardation. There was no intraventricular hemorrhage listed as an immediate cause of death.

Intrauterine hypoxia and birth asphyxia have reduced along the study period (from $25.7 \%$ to $20 \%$ ); however, the number of infection-related deaths (from $9.1 \%$ to $21.5 \%$ ) and disorders related to short gestation and low birth weight (extreme immaturity) have increased (from $19.7 \%$ to $27.7 \%$ ) over the last decade. Isoimmunization and twinto-twin transfusion syndrome have disappeared as cause of death in this group over the last tenyear period.
When considering the leading causes of perinatal death (Table 5), premature rupture of membranes (PROM) leading to chorioamnionitis / sepsis occurred in 31 cases (23.7\%).

Birth-related conditions, basically uncontrolled uterine dynamics that results in a preterm delivery, was the cause of 25 deaths $(19.1 \%)$ and became the third leading cause of death, after infection and fetal compromise due to placental, umbilical cord and membrane complications.

The most important associated maternal pathology was hypertension (22 cases), which was the leading cause of death in 19 of these. Placental pathology occurred in 20 cases: 14 were cases of placental abruption, sometimes associated with maternal hypertension $(10.7 \%)$; the rest of the cases were related to placenta praevia or placental infarction. Umbilical cord pathology (cord entanglement, cord prolapse) was the main cause of death in 9 cases.

It should be noted that 31 deaths were related to multiple pregnancies (21 twin gestations and

TABLE 3. Analysis of mortality rates over the perinatal period distributed in ten-year periods. Mann-Whitney test

\begin{tabular}{lcccc}
\hline & $\begin{array}{c}\mathbf{1 9 9 1 - 2 0 0 0} \\
\text { mean } \pm \text { SD }\end{array}$ & $\begin{array}{c}\mathbf{2 0 0 1 - 2 0 1 0} \\
\text { mean } \pm \text { SD }\end{array}$ & U & \multicolumn{1}{c}{. } \\
\hline Fetal mortality rate* & $384.44 \pm 123.14$ & $233.88 \pm 101.15$ & 19.00 & $0.019^{*}$ \\
Early neonatal mortality rate & $242.49 \pm 153.80$ & $359.19 \pm 241.89$ & 35.00 & 0.256 \\
Perinatal mortality rate & $528.81 \pm 143.98$ & $487.43 \pm 236.53$ & 47.50 & 0.850 \\
\hline
\end{tabular}

$\mathrm{U}$ : Mann-Whitney $\mathrm{U} ; p$ : value of significance; * $p<0.05$.

TABLE 4. Immediate cause of perinatal death in newborn infants with a birth weight of less than $1000 \mathrm{~g}$. ICD-9

\begin{tabular}{|c|c|c|c|}
\hline & $1991-2000$ n (\%) & 2001-2010 n (\%) & Total n (\%) \\
\hline Intrauterine growth retardation and fetal malnutrition (764) & $2(3.1)$ & $5(7.7)$ & $7(5.3)$ \\
\hline Disorders relating to short gestation and low birth weight (765) & $13(19.7)$ & $18(27.7)$ & $31(23.7)$ \\
\hline Birth trauma (767) & $2(3.1)$ & 0 & $2(1.5)$ \\
\hline Intrauterine hypoxia and birth asphyxia (768) & $17(25.7)$ & $13(20)$ & $30(22.9)$ \\
\hline Neonatal respiratory distress syndrome (769) & $3(4.5)$ & $6(9.2)$ & $9(6.9)$ \\
\hline Infections specific to the perinatal period (771) & $6(9.1)$ & $14(21.5)$ & $20(15.3)$ \\
\hline Fetal and neonatal hemorrhage (772) & $7(10.6)$ & 0 & $7(5.3)$ \\
\hline Hemolytic disease of fetus or newborn, due to isoimmunization (773) & $3(4.5)$ & 0 & $3(2.3)$ \\
\hline $\begin{array}{l}\text { Fetus or newborn affected by multiple pregnancy } \\
\text { (twin-to-twin transfusion syndrome) (761.5) }\end{array}$ & $4(6.1)$ & 0 & $4(3.1)$ \\
\hline Congenital anomalies, deformities and chromosomal anomalies (740-759) & $6(9.1)$ & $5(7.7)$ & $11(8.4)$ \\
\hline Unknown & $3(4.5)$ & $4(6.2)$ & $7(5.3)$ \\
\hline Total & $66(50.4)$ & $65(49.6)$ & $131(100)$ \\
\hline
\end{tabular}

The immediate cause is that which results in death to the fetus or newborn infant.

$\%=$ percentage over the total number of perinatal deaths. 
10 multiple gestations with more than two fetuses), 7 occurred in the 1991-2000 period and 24, in the 2001-2010 period. In twin gestations, the most frequent leading causes of death have been an uncontrolled uterine dynamics leading to preterm birth (12 cases) and premature rupture of membranes (PROM) leading to infection (8 cases).

\section{DISCUSSION}

Perinatal mortality studies pose multiple hurdles because of the problem of establishing definitions and diagnostic criteria, ${ }^{7}$ the problem of under-reporting ${ }^{8-13}$ which prevents obtaining "exact" statistics, and the problem of cause analysis since there is no universal classification system applicable to perinatal deaths, and such causes might involve the mother, the fetus or the newborn infant (or both) and pregnancy or delivery (or both), and sometimes it is difficult to distinguish and classify these causes. ${ }^{7,14,15}$

The study of mortality in this group is harder because the extent of under-reporting is even larger. ${ }^{8-13}$ In fact, no common reporting and analysis systems have been established in developed countries regarding perinatal mortality; there are no equivalent reporting systems within each country that would serve for a study of this type of mortality and to establish an actual comparison among hospitals, communities and countries.

In Spain, a few investigations ${ }^{8-10}$ estimate that under-reporting of national perinatal mortality reaches $24-35 \%$; and establish a relation between certain circumstances and this phenomenon, such as low birth weight, early gestational age, and legal criteria or unclear definitions regarding the report of such deaths. The group of newborn infants analyzed in this article is precisely the one that meets all these issues.

In spite of such difficulties, health organizations recognize that low birth weight newborn infants and preterm infants, especially those born with less than $1000 \mathrm{~g}$, have the highest morbidity and mortality rates. ${ }^{1,3}$ This group accounts for a very low percentage of total births $(0.7 \%){ }^{16}$ however, it contributes to $20-50 \%$ of mortality during the first year of life. ${ }^{16-18}$

In Europe, ${ }^{3}$ this group of newborn infants accounts for $29.3 \%$ of perinatal deaths; in our research, such rate is a bit higher $(31.41 \%)$, probably because of the under-reporting bias and biased European statistics, which are estimations based on data provided by certain hospitals in each country.

According to the official data provided by the Spanish National Statistics Institute (Instituto $\mathrm{Na}$ cional de Estadística, INE) ${ }^{4}$ fetal mortality rate in this group ranges from $207.9 \%$ o to $356.6 \%$. Under-reporting at a national level is probably the cause for the higher fetal mortality rates found in our research.

When analyzing the results, the fluctuation of rates in some of the years, together with their wide range, have definitely influenced their lack of statistical significance. Fetal mortality does present a statistically significant reduction; however, early neonatal mortality and perinatal mortality have not reduced. Perinatal mortality has reduced slightly, but insignificantly.

This slowing down of the decrease in mortality rates may be explained by the fact that it is

TABLE 5. Leading cause of perinatal death in newborn infants with a birth weight of less than $1000 \mathrm{~g}$. ICD-9

\begin{tabular}{|c|c|c|c|}
\hline & $1991-2000$ n (\%) & $2001-2010$ n (\%) & Total n (\%) \\
\hline Fetus or newborn affected by maternal condition $(760)^{*}$ & $11(16.7)$ & $8(12.3)$ & $19(14.5)$ \\
\hline Fetus or newborn affected by premature rupture of membranes (761) & $12(18.2)$ & $19(29.2)$ & $31(23.7)$ \\
\hline $\begin{array}{l}\text { Fetus or newborn affected by complications of placenta, } \\
\text { cord, and membranes ( } 762 \text { ) }\end{array}$ & $13(19.7)$ & $16(24.6)$ & $29(22.1)$ \\
\hline $\begin{array}{l}\text { Fetus or newborn affected by other complications } \\
\text { of labor and delivery ( } 763)\end{array}$ & $12(18.2)$ & $13(20)$ & $25(19.1)$ \\
\hline Conditions originating in the perinatal period (764-779) & $11(16.7)$ & $7(10.8)$ & $18(13.8)$ \\
\hline Unknown & $7(10.5)$ & $2(3.1)$ & $9(6.8)$ \\
\hline Total & $66(50.4)$ & $65(49.6)$ & $131(100)$ \\
\hline
\end{tabular}

The leading cause is the condition/disease of the fetus or newborn infant, or the main maternal condition/disease involving the fetus or newborn infant, or the complications of ovular appendages contributing to perinatal death.

$\%=$ percentage over the total number of perinatal deaths.

* = all cases due to maternal hypertension. 
reaching rates that are hard to reduce. This has been pointed out by other research ${ }^{19}$ suggesting that there are certain "biological limits" and that it would be very difficult to reach reductions below such limits based on current scientific knowledge. ${ }^{20}$

Occasionally, certain situations leading to fetal death are unavoidable, as in the case of umbilical cord accidents in preterm gestations.

On the other side, it is difficult to reduce maternal conditions ${ }^{21,22}$ or pregnancy induced complications (hypertension, placental problems, etc.), but they may be controlled more closely, ${ }^{23}$ and these result in an increase of iatrogenic delivery of preterm newborn infants.

In fact, in this study, maternal hypertension was the leading factor contributing to this type of mortality associated with maternal conditions. Some studies ${ }^{24}$ suggest that hypertension related to preterm delivery is the main cause of early neonatal and infant mortality, because it leads to forcing a preterm birth and also because hypertension may cause placental dysfunction, which results in fetal and placental complications ${ }^{25}$ leading to fetal or neonatal death. So far, all interventions targeted at preventing hypertension during pregnancy have not been effective.

When analyzing causes of death, the problem regarding the definition and classification of causes of death comes up, since the different investigations on this field do not analyze them in the same manner, ${ }^{12,13}$ and immediate and main causes overlap, as pointed out in different studies. ${ }^{7,14,26}$ For this reason, it is necessary to establish homogeneous and contrasting criteria that will serve in the future as guidelines for taking actions and reporting. ${ }^{15}$

Disorders of short gestation and low birth weight (extreme immaturity) constitute, in this research, the most common immediate cause of death $(23.7 \%)$, and it has also increased over the years (1991-2000: 19.7\% vs. 2001-2010: 27.7\%), and this is consistent with the increased number of multiple pregnancies in our facilities over the last decade. This circumstance has likely contributed to the high percentage of this cause of death in our study (23.7\%) when compared to what has been reported by other authors, ${ }^{17}$ however, most investigations have shown percentages that were similar ${ }^{15,27}$ to the results presented here, making extreme immaturity one of the immediate, main causes of death. ${ }^{26}$

Severe malformations were not an important cause of mortality (only 11 cases) in this group of newborn infants. This is because of technological advances and the specific training of professionals, which allow to make a prenatal diagnosis before reaching 22 weeks of gestations and to make decisions regarding pregnancy termination. The low percentage of malformations $(8.4 \%)$ in this study differs from what has been referred by other authors (14\%). ${ }^{17,28}$

Several investigations ${ }^{17,29}$ indicate that intraventricular hemorrhage is one of the top causes of death in this group of newborn infants; however, there was no case in this study, probably because of the standardized use of corticosteroids for fetal pulmonary development and the consequent protection of the central nervous system. Hyaline membrane disease, which is also an important immediate cause of mortality, accounted for $6.9 \%$ of deaths in this research, contrasting with what has been referred by other authors. ${ }^{17}$

Preterm PROM is still one of the major obstetric problems today. ${ }^{30,31}$ In this study, it caused the death of 31 of these newborn infants $(23.7 \%)$, together with suspected chorioamnionitis in most of the cases, and this has determined that pregnancy termination was decided for some of these gestations (iatrogenic preterm delivery), sometimes even in spite of great immaturity. Infection/ sepsis/septic shock are one of the main causes of death, ${ }^{32}$ with great variations (14.3-21.4\%); ${ }^{17,28}$ and reaching $53.7 \%$ in some investigations. ${ }^{29}$ In this research, it occurred in $15.3 \%$ of the cases and is the third leading cause of death, following disorders of short gestation and low birth weight (extreme immaturity), and intrauterine hypoxia and birth asphyxia.

Preterm PROM ${ }^{33}$ together with its consequences, should therefore be the subject of further obstetric research. In the HUSC, our protocol indicates to administer progesterone to women at risk of preterm delivery, corticosteroids when there is a chance of having a preterm delivery, and antibiotics in the case of PROM. This last indication may have contributed to the lower incidence of infection as cause of death in relation to other studies.

The advance in assisted reproductive technology has increased the number of twin pregnancy problems. ${ }^{34}$ It is a fact that morbidity and mortality are 3-7 times higher than in singleton pregnancies. ${ }^{35}$

Recent studies ${ }^{29}$ have shown that perinatal mortality is 3.6 times higher and that fetal mortality is 5.9 times higher. Such high morbidity and mortality rates are caused by the high incidence 
of antepartum complications, preterm delivery and uteroplacental insufficiency; ${ }^{35}$ together with higher maternal morbidity and mortality and an increase in health expenses and the resulting emotional cost for the family.

In our study, the number of stillbirths in multiple pregnancies reached a mortality rate of $23.7 \%$ and it has tripled over the last decade (from 7 to 24).

\section{CONCLUSIONS}

The group of newborn infants with a birth weight of less than $1000 \mathrm{~g}$ accounts for $0.47 \%$ of all newborn infants; however, they contribute to more than $30 \%$ of perinatal mortality.

The main immediate causes of death are extreme immaturity, intrauterine hypoxia and infection.

Multiple gestations, maternal hypertension, infection caused by premature rupture of membranes and the uterine dynamics leading to preterm delivery are the leading causes related to death in this group of newborn infants.

The reduction in mortality rates in this group is undergoing a slowdown.

\section{BIBLIOGRAPHY}

1. Organización Mundial de la Salud. Estadísticas Sanitarias Mundiales. 2011. [Accessed on: July 27, 2012]. Available at: http://www.who.int/whosis/whostat/ES_whs2011_full. pdf.

2. Zupan J. Perinatal mortality in developing countries. $N$ Eng J Med 2005;352(20):2047-8.

3. EURO-PERISTAT Project, with SCPE, EUROCAT, EURONEOSTAT. European Perinatal Health Report. 2008. [Accessed on: July 27, 2012]. Available at: http//www.sante. public.lu/publications/sante-file-vie/petite-enfance/europeanperinatal-health-report/european-perinatal-healthreport.pdf.

4. Anuario Estadístico de España. Años 2000-2009. Instituto Nacional de Estadística. Madrid. [Accessed on: August 6, 2012]. Availableat:http://www.ine.es/proyser/pubweb/ anuarios_mnu.htm.

5. Carroli G, Villar J, Piaggio G, Khan-Neelofur D, et al. WHO systematic review of randomised controlled trials of routine antenatal care. Lancet 2001;357(9268):1565-70.

6. OMS. Presentación estadística. In: Clasificación Estadística Internacional de Enfermedades y Problemas Relacionados con la Salud. 10a Revisión Clínica. Vol 2: Manual de Instrucciones. Washington: Organización Panamericana de la Salud; 1997. Págs.125-39.

7. OMS. Certificación Médica de Causa de Defunción. 4ta. ed. Ginebra: Organización Mundial de la Salud, 1980.

8. Mosquera C, González-Rico M. Calidad del registro de muertes perinatales. Asturias, 1986-1990. Gac Sanit 1994;8(42):112-6.

9. FerrandoJ, BorellC, Ricart M,Plasència A. Infradeclaración de la mortalidad perinatal: experiencia de 10 años de vigilancia activa en Barcelona. Med Clin (Barc) 1997;108(9):3305.

10. Revert M, Rué M, Moreno C, Pérez G, et al. Análisis del in- frarregistro de mortalidad perinataly sus factores asociados en una región sanitaria de Cataluña. Gac Sanit 1998;12:6370.

11. Freitas A, Puigdefàbregas A, Gispert R, Barés M, et al. La mortalidad perinatal según 2 fuentes de información. Gac Sanit 2008;22(3):278-81.

12. Castilla J, Moreno C, Eguino E. Validez de las Estadísticas de Mortalidad infantil en Navarra. Gac Sanit 1992;6:153-6.

13. Cirera 1, Martínez C, Salmerón D, Navarro C. Subcertificación de las muertes perinatales en obstetricia y neonatología. An Pediatr 2008;69(2):129-33.

14. Tosca R, Aguilera R, Bellido J y Grupo de Estudios Neonatales de la Comunidad Valenciana (GEN-CV). Causas de mortalidad neonatal en la Comunidad Valenciana. $A n$ Esp Pediatr 2002;57(6):565-9.

15. Santos JG, Gallego MJ, Imaz A, Martínez JV, et al. Mortalidad neonatal del Hospital Universitario de Valladolid (HUV) en la década de los 90. Bol Pediatr 2004;44:113-9.

16. Suárez A, Rodríguez D. Morbimortalidad en neonatos de muy bajo peso en el Hospital Yvan Portuondo. Estudio de 5 años (2003-2007). [Accessed on: September 1,2011]. Available at: http://www.monografias.com/trabajos-pdf4/ morbimor-talidad-neonatos-muy-peso/morbimortalidadneonatos-muy-peso.pdf.

17. Molina OR, Regalado A. Recién nacido de peso extremo. Rev Cubana Obstet Ginecol 2010;36(2)165-75.

18. Bosch S, López A, Melchor I, Ibáñez I, et al. Informe Registro de Mortalidad Perinatal de la Comunidad Valenciana, 2006-2007. Conselleria de Sanitat. Generalitat Valenciana, 2009.

19. Ruiz M, Nieto AM. Evolución de la mortalidad infantil, neonatal y postneonatal en Andalucía, 1975-1998. Rev Esp Salud Pública 2003;77:363-71.

20. Rada D, Cotero A, Centeno C, Valls A. Evolución de la mortalidad neonatal y perinatal en los hospitales del Grupo de Estudios Neonatales Vasco-Navarro (GEN-VN) en el período 2000-2006. An Pediatr (Barc) 2009;70(2):143-50.

21. Clowse M, Magder LS, Witter F, Petri M. Early Risk Factors for Pregnancy Loss in Lupus. Obstet Gynecol 2006; 107:293-9.

22. Empson M, Lassere M, Craig J, Scott J. Prevention of recurrent miscarriage for women with antiphospholipid antibody or lupus anticoagulant. Cochrane Database Syst Rev 2005:CD002859.

23. Menezes EV, Yakoob MY, Soomro T, Haws RA, et al. Reducing stillbirths: prevention and management of medical disorders and infections during pregnancy. BMC Pregnancy and Childbirth 2009;9 (Suppl 1):S4.

24. Villar J, Ezcurra EJ, Gurtner de la Fuente V, Campodonico L. Preterm delivery syndrome: the unmet need. Res Clin Forums 1994;16:9-39.

25. Sibai BM. Caring for women with hypertension in pregnancy. JAMA 2007;298(13):1566-8.

26. Cruz E, Lapresta M, Crespo R, José Y, et al. Análisis de la mortalidad perinatal, Hospital Miguel Servet, Zaragoza, España: 2000-2009. Rev Chil Obstet Ginecol 2011;76(1):3-9.

27. Rivera MA, Hernández M, Hernández G, Llano I, et al. Análisis de la mortalidad neonatal precoz en el Instituto Nacional de Perinatología (1991-2001). Perinatol Reprod Hum 2005;19:13-21.

28. Yllescas-Medrano E, García-Graullera MG, FernándezCarrocera LA. Valoración del riesgo de morbi-mortalidad en recién nacidos con peso $\leq$ de $1,500 \mathrm{~g}$, en una unidad hospitalaria de tercer nivel. Perinatol Reprod Hum 2005; 19:87-93.

29. Centre for Maternal and Child Enquiries (CMACE) Perinatal Mortality 2008: United Kingdom. CMACE: London; 2010. 
30. Saavedra D, Valdés S, Bardales J, Essien J, et al. Morbimortalidad perinatal de la rotura prematura de membrana en el embarazo pretérmino. Clin Invest Gin Obst 2006;33(3):1026.

31. Ananth CV, Oyelese Y, Srinivas N, Yeo L, et al. Preterm Premature Rupture of Membranes, Intrauterine Infection, and oligohydramnios: Risk Factors for Placental Abruption. Obstet Gynecol 2004;104:71-7.

32. Moraes M, Cancela MJ, Repetto M, Gutiérrez C, et al. Corioamnionitis histológica en el recién nacido menor de 1.000 gramos. Incidencia y resultados perinatales Rev Soc Bol Ped 2008;47(1):53-9.
33. Barros FC, Bhutta ZA, Batra M, Hansen TN, et al. Global report on preterm birth and stillbirth (3 of 7): evidence for efectiveness of interventions. BMC Pregnancy Childbirth 2010;10(Suppl 1):S3.

34. Contribution of assisted reproductive technology and ovulation-inducing drugs to triplet and higher-order multiple births-United States, 1980-1997. MMWR Morb MortalWkly Rep 2000;49:535-8.

35. Sherer DM. Adverse perinatal outcome of twin pregnancies according to chorionicity: review of the literature. Am J Perinatol 2001;18:23-37. 